\title{
MAKNA TEOLOGIS KETURUNAN SEBAGAI PEMBERIAN ALLAH BAGI KELUARGA DALAM PERJANJIAN LAMA
}

\author{
Yohanes K. Susanta
}

\begin{abstract}
Abstrak:
Barrenness is a serious problem for couples in a culture that emphasizes the importance of generating descendants such as one of the time of the Judeo-Christian Scripture. This writing offers a theological reflection that comes from the Old Testament. Children is God's grace for the family. Nevertheless, having no children should no longer be seen solely as a burden for a couple but rather as part of the mystery of God's grace for their lives as family. God may use barrenness to increase faith in God. God may direct barren married couple to use their time and freedom to serve Him. Still, God may use barrenness as an opportunity for adoption. Finally, God may use barrenness as a witness to those who have children to cherish them as God's grace.
\end{abstract}

\section{Kata-kata Kunci:}

kemandulan, keturunan, Israel, keluarga, Perjanjian Lama

\section{PENDAHULUAN}

Indonesia merupakan salah satu negara paling padat penduduk di dunia. Berdasarkan data sensus penduduk tahun 2010, jumlah penduduk Indonesia adalah 237.641.326 jiwa. ${ }^{1}$ Untuk mengatasi laju pertumbuhan penduduk tersebut, pemerintah melakukan sejumlah upaya, salah satunya dengan mencanangkan program Keluarga Berencana (KB) yang sudah dimulai sejak tahun 1957 dan menjadi program resmi pemerintah dengan ditandainya pencanangan "Hari Keluarga Nasional" pada 29 Juni $1970 .^{2}$ Salah satu slogan dari program KB adalah "dua anak cukup, lakilaki atau perempuan sama saja." Meski program tersebut berjalan sukses, akan tetapi hal itu tidak menyurutkan niat keluarga-keluarga untuk memperoleh banyak keturunan dari perkawinan mereka. Apalagi, program KB juga tidak dimaksudkan untuk menghentikan kelahiran melainkan untuk menekan jumlah kelahiran. Kenyataan ini menunjukkan meski ada upaya mengurangi jumlah kelahiran, namun toh kehadiran keturunan tetap dianggap sebagai hal penting bagi kebanyakan keluarga di Indonesia.

Dengan demikian, kehadiran seo-rang anak merupakan peristiwa yang dinantikan oleh setiap keluarga. Kegembiraan akan lebih dirasakan oleh pasangan suami-istri yang sudah lama tidak memiliki anak ketika sang bayi telah lahir. Tidak mengherankan jika sebagian besar pasangan yang telah menikah berharap bahwa mereka kelak akan memiliki keturunan, sama seperti keluargakeluarga lainnya. Dalam kehidupan rumah tangga, keinginan memiliki anak dari pasangan suami-istri seringkali disertai dengan tuntutan dari orangtua atau pihak keluarga besar. Hal tersebut membuat 
pasangan yang belum memiliki keturunan dalam waktu yang cukup lama akan berusaha keras untuk segera memiliki anak. Berbagai usaha baik medis maupun tradisional, bahkan yang berhubungan dengan budaya serta tradisi keagamaan akan dilakukan.

Berdasarkan fenomena tersebut, dapat ditarik kesimpulan awal bahwa harapan untuk memiliki keturunan oleh setiap keluarga umumnya dianggap sebagai bagian dari tujuan perkawinan. Harapan senada dapat dapat dijumpai dalam kisah-kisah Alkitab. Oleh karena itu, tulisan ini akan berusaha memahami arti penting keturunan bagi keluarga Israel kuno dan kemudian menarik pelajaran serta pemahaman yang tepat bagi keluarga masa kini yang bergumul dengan isu keturunan dan kesulitan memiliki anak (kemandulan).

\section{NILAI ANAK BAGI SEBAGIAN BESAR SUKU DI INDONESIA}

Dalam sebuah acara resepsi pernikahan, salah satu perkataan atau ungkapan khas yang seringkali terdengar dari para undangan adalah: "Selamat menempuh hidup baru, cepat dapat momongan, ya." Selain itu, keluarga dan anak seringkali menjadi topik pembicaraan ketika dua sahabat lama bertemu kembali. Kesuksesan dan kekayaan rupanya kurang dibahas. Hal tersebut sekaligus mengindikasikan betapa penting nilai anak dalam kehidupan seseorang atau keluarga yang melebihi nilai harta kekayaan yang dimiliki. ${ }^{3}$ Berdasarkan fenomena yang terjadi dalam konteks Indonesia tersebut, tampak bahwa masyarakat masih menganggap bahwa salah satu tujuan perkawinan adalah untuk memperoleh keturunan.

Bagi sebagian besar suku di Indonesia, anak merupakan dambaan dan harapan bagi setiap keluarga. Di dalam budaya Jawa, misalnya, dikenal ungkapan "banyak anak, banyak rezeki." Maksud dari ungkapan tersebut adalah: keluarga yang memiliki banyak anak berharap bahwa keluarga tersebut akan dipenuhi dengan rezeki dan hidup dengan sejahtera. Nilai penting seorang anak juga dapat dijumpai dalam masyarakat Batak Toba. Bagi masyarakat
Batak Toba, tujuan hidup yang ideal dapat tercapai dengan menjalankan tiga misi budaya yaitu hagabeon (kebahagiaan), hamoraon (kekayaan) dan hasangapon (kehormatan). ${ }^{4}$ Bagi masyarakat Batak Toba, kekayaan yang paling berharga dalam kehidupan mereka adalah keturunan, anakcucu. $^{5}$

Pentingnya memiliki keturunan juga dijumpai dalam kehidupan masyarakat Bali. Keluarga yang tidak memiliki anak dianggap sebagai keluarga yang tidak beruntung. Sebutan yang muncul untuk menggambarkan kondisi tersebut adalah Nang Pocol dan Men Pocol atau Nang Bekung dan Men Bekung (pocol berarti rugi sedangkan bekung berarti mandul. Nang berarti ayahnya sedangkan Men berarti ibunya). ${ }^{6}$ Bagi keluarga Bali, mempunyai anak sangat penting karena hal itu dianggap menjadi salah satu cara untuk membayar hutang kepada orangtua. ${ }^{7}$ Hal tersebut dipertegas dengan adanya pandangan bahwa seseorang baru mencapai tujuan hidup setelah memiliki cucu, yang tampak dalam ungkapan "I cucu nyupat I kaki" (cucunya menyelamatkan kakeknya). ${ }^{8}$

Hal serupa berlaku pula bagi suku Toraja. Bagi suku Toraja, keturunan sangat penting karena dua hal mendasar. Pertama, tongkonan (rumah tradisional Toraja) menjadi tanda persekutuan dan persaudaraan sesama turunan nenek. Karena itu, jika tidak ada keturunan, tidak ada yang akan membangun tongkonan. Kedua, adanya pesta kematian (rambu solo'). Jika tidak ada keturunan, maka tidak ada yang akan melaksanakan upacara kematian. ${ }^{9}$ Singkat kata, kehadiran seorang anak (keturunan) merupakan harapan bagi hampir seluruh keluarga di Indonesia.

Berdasarkan fenomena tersebut, dapat ditarik kesimpulan bahwa bagi sebagian besar suku di Indonesia, keturunan memiliki arti penting dalam kehidupan perkawinan pasangan suami-istri. Kondisi serupa juga dapat dijumpai dalam beberapa kisah tokoh dalam Alkitab. Oleh sebab itu, setelah memperlihatkan pentingnya keturunan bagi sebagian besar suku di Indonesia, bagian selanjutnya dari tulisan ini akan dimulai dengan penelusuran beberapa teks-teks dan 
kisah Alkitab khususnya Perjanjian Lama yang mengindikasikan pentingnya keturunan bagi keluarga Israel. Hal tersebut bertujuan untuk menarik pelajaran dari kisah-kisah keluarga dalam Alkitab yang bergumul dengan persoalan tersebut. Pentingnya keturunan bagi orang Israel dapat dijumpai dalam beberapa kisah dalam Alkitab. Salah satunya dapat dilihat melalui dua bentuk perkawinan yang mengindikasikan pentingnya memiliki keturunan bagi keluarga dan masyarakat Israel.

\section{PERKAWINAN POLIGAMI DAN LEVIRAT DALAM KELUARGA ISRAEL KUNO}

Praktik perkawinan monogami yang terjadi pada masa kini dapat dijumpai dalam Alkitab. Roland de Vaux mengatakan, "bagaimanapun, bentuk paling umum dari pernikahan di Israel adalah monogami." 10 Israel kuno memandang perkawinan sebagai relasi perjanjian (covenant). Indikasi tersebut misalnya terlihat dalam Amsal 2:7 dan Maleakhi 2:14 memperlihatkan bahwa perkawinan merupakan ikatan perjanjian dan Tuhan menjadi saksi perkawinan tersebut. ${ }^{11}$

Meskipun demikian, Alkitab juga menunjukkan bahwa masyarakat pada zaman itu mempraktikkan bentuk perkawinan yang pada masa kini dianggap tidak lumrah yaitu perkawinan poligami dan levirat. Poligami dan levirat adalah dua bentuk perkawinan dalam Perjanjian Lama. Poligami merupakan perkawinan antara laki-laki dengan banyak istri. Alkitab mencatat beberapa contoh laki-laki atau suami yang memiliki istri lebih dari satu misalnya Lamekh, Abraham, Yakub, Daud, Salomo, dan lainlain. Perkawinan poligami juga membuka peluang bagi seorang laki-laki (suami) untuk berhubungan dengan budak perempuan demi melahirkan keturunan baginya seperti yang dijumpai dalam kisah Abraham, Sara dan Hagar, budaknya.

Bagi orang yang hidup pada zaman modern, kesan negatif dari bentuk perkawinan poligami akan langsung terlihat. Bentuk perkawinan demikian memang lahir dalam budaya yang mengedepankan dominasi lakilaki, termasuk dalam hidup berkeluarga.
Akan tetapi perlu diingat bahwa bentuk perkawinan yang demikian adalah sesuai dengan konteks zaman pada waktu itu. Banyaknya istri berarti peluang untuk memiliki keturunan akan semakin besar. Meski demikian, hal lain yang perlu diingat adalah - sesuai catatan de Vaux - bentuk perkawinan poligami berpotensi besar menimbulkan konflik antaristri dalam satu rumah sebab istri yang mandul biasanya akan dihina dan direndahkan oleh istri yang lain (misalnya sikap Penina kepada Hana, atau Hagar kepada Sara). ${ }^{12}$ Sikap suami yang cenderung lebih memperhatikan seorang istri juga akan turut menimbulkan kecemburuan dari istri yang lain (Kejadian 29:30-31). ${ }^{13}$ Bentuk perkawinan poligami ternyata berpotensi besar untuk menghasilkan lebih banyak masalah dibandingkan bentuk perkawinan monogami. ${ }^{14}$

Bentuk perkawinan selanjutnya adalah perkawinan Levirat atau perkawinan ipar (Ulangan 25:-10). Istilah "levirat" berasal dari bahasa Latin levir, yang dalam bahasa Ibrani dipakai istilah yabam (ipar lakilaki). ${ }^{15}$ Di dalam hukum perkawinan levirat, dikatakan bahwa apabila suami dari seorang istri meninggal tanpa keturunan, maka saudara laki-laki dari suami tersebut harus menikahi istri saudaranya untuk membangkitkan keturunan baginya. Di dalam Alkitab ada dua contoh perkawinan demikian yaitu dalam kisah Tamar (Kejadian 38:6-7) dan kisah Rut. ${ }^{16}$ Anak-anak hasil dari perkawinan tersebut akan menjadi ahli waris dari saudara laki-laki yang telah meninggal supaya "nama itu jangan terhapus dari antara orang Israel" (Ulangan 25:6). Apabila seorang laki-laki menolak untuk menikahi ipar perempuannya yang telah menjadi janda, ia akan dipermalukan di depan umum" (Ulangan 25:7-10 ; Rut 4:1-7). ${ }^{17}$ Dari kisah tersebut terlihat jelas betapa pentingnya keturunan bagi keluarga Israel. Dalam konteks zaman tersebut juga tampak jelas bahwa tujuan dari perkawinan, pertama-tama dipandang sebagai usaha untuk mendapatkan keturunan.

Dua bentuk perkawinan yang berlaku pada zaman tersebut secara tidak langsung mempertontonkan sistem budaya yang menekankan dominasi laki-laki dalam kehidupan keluarga Israel. Dari kedua bentuk 
perkawinan tersebut juga dapat disimpulkan bahwa tujuan perkawinan bagi orang Israel adalah untuk memiliki anak (dalam jumlah yang besar) demi meneruskan garis keturunan keluarga.

\section{KETURUNAN SEBAGAI PENJAMIN MASA DEPAN KELUARGA ISRAEL}

Harapan untuk mempunyai banyak keturunan seolah menjadi prioritas dalam perencanaan suami-istri dan keluarga besar di Israel. Hal tersebut salah satunya dapat dijumpai dalam kisah peminangan Ribka untuk menjadi istri Ishak. Sebelum Ribka pergi ke rumah mertuanya untuk menjadi istri dari Ishak, juru bicara keluarga mengucapkan sepenggal kalimat yang berisi harapan, "Saudara kami, moga-moga engkau menjadi beribu-ribu laksa, dan mogamoga keturunanmu menduduki kota-kota musuhnya" (Kejadian 24:60). Ungkapan yang serupa juga diberikan kepada Rut sebelum pernikahannya dengan Boas (Rut 4:11-12).18 Ungkapan tersebut secara sederhana memperlihatkan bahwa keturunan menjadi penting bagi masyarakat Israel pada masa itu.

Selain itu, bagi orang Israel, kehidupan adalah sesuatu yang dipandang sakral sekaligus pemberian Allah. Hal yang menarik dalam Mazmur 127:3 dikatakan bahwa anak bukan hanya pemberian Tuhan melainkan milik pusaka Tuhan. ${ }^{19}$ Dengan demikian, secara tidak langsung, memiliki keturunan berarti selaras dengan kehendak Allah. Memiliki keturunan berarti menyambung kehidupan keluarga dan kehidupan tersebut adalah anugerah dari Allah. Memiliki keturunan berarti menjamin kehidupan keluarga. Bahkan menjamin kehidupan bangsa.

Seto Marsunu mengutip Midrash Kidung Agung yang memberikan ilustrasi menarik tentang hal tersebut,

Ketika Israel berdiri di hadapan Gunung Sinai untuk menerima Taurat, Yang Kudus berkata kepada mereka, "Apakah Aku akan memberimu Taurat? Berilah Aku penjamin bahwa engkau akan menaatinya, maka Aku akan memberikannya kepadamu." Mereka menjawab, "Penguasa alam semesta, nenek moyang kami akan menjadi penjaminnya."...
Firman Allah kepada mereka, "Aku tidak dapat menemukannya dalam nenek moyangmu... Berikanlah kepada-Ku penjamin, maka Aku akan memberikannya kepadamu." Kata mereka, "Penguasa alam semesta, para nabi kami adalah penjamin kami." Ia menjawab, "Aku tidak dapat menemukannya pada mereka..." Mereka pun berkata kepada-Nya, "Anak-anak kami adalah penjamin kami." Allah pun menjawab, "sesungguhnya, ini adalah penjamin yang baik; demi mereka Aku akan memberikannya kepadamu." 20

Itu sebabnya setiap keluarga Israel sangat menantikan kehadiran anak dalam keluarga mereka. Berbagai usaha dilakukan untuk memperoleh seorang anak yang tidak hanya menjadi ahli waris tetapi sekaligus menjadi kebanggaan dan penjamin keluarga Israel. Karena itu, menurut Perdue, tidak mengherankan jika reproduksi merupakan salah satu fungsi penting dari keluarga (Kejadian 1:28; 9:1) dan perempuan memiliki peran yang sangat penting dalam menghasilkan banyak keturunan (Kejadian 24: 60). ${ }^{21}$ Keturunan yang dihasilkan akan menyambung nama nenek moyang sekaligus memelihara tradisi keluarga serta menjadi penjamin kehidupan umat secara keseluruhan.

\section{KEMANDULAN SEBAGAI CELA KELUARGA ISRAEL}

Apabila keturunan dipandang sebagai harapan bagi keluarga dan masyarakat Israel, maka tentunya kemandulan menjadi persoalan serius bagi setiap keluarga Israel. Itu sebabnya, di dalam Alkitab dijumpai kisah-kisah tentang keluarga mandul yang berusaha untuk keluar dari situasi tersebut. Salah satu kisah yang terkenal dalam Alkitab adalah kisah Abraham, Sara dan Hagar. Alkitab menceritakan tentang Sara yang mandul, yang memberikan Hagar, budaknya, kepada Abraham untuk membangkitkan keturunan baginya meskipun hal tersebut tidak sesuai dengan rencana Tuhan (Kejadian 16:1-16).

Kemandulan ibarat musuh bagi setiap keluarga Israel. Kemandulan dipandang sebagai aib keluarga. Dalam konteks zaman itu (ilmu kedokteran belum maju), perempuan dianggap sebagai penyebab ketidak- 
mampuan untuk memiliki keturunan. Gambaran tentang istri mandul adalah salah satu dari gambaran kesedihan dan rasa tertolak yang paling kuat dalam Alkitab. ${ }^{22}$ Seorang istri yang tidak dapat mempunyai anak sering kali menjadi objek ejekan karena ketidakmampuannya mengandung dan melahirkan anak, khususnya anak laki-laki (Kejadian 30:1-2, 23; 1 Samuel 1:6-10). ${ }^{23}$ Dalam keadaan demikian, kita dapat memperkirakan bahwa dari sudut pandang sosial, perempuan akan merasa malu sedangkan dari sudut pandang psikis, kemungkinan besar perempuan atau istri akan sangat tertekan. Belum lagi dari sudut pandang keagamaan atau kerohanian, ia mungkin merasa bersalah karena berpikir bahwa ketidakmampuannya menghasilkan keturunan adalah karena dosa yang ia perbuat di masa lalu.

Kondisi tersebut dapat dijumpai dalam kisah Hana, Ibu Samuel. Ia merasa malu dan sakit hati karena memperoleh penghinaan dari Penina, istri kedua suaminya, Elkana (1 Samuel 1:6-8). Meskipun bukan hanya istri yang menanggung beban berat tersebut (suami juga merasakannya), ${ }^{24}$ akan tetapi dalam konteks zaman itu, posisi laki-laki sedikit lebih menguntungkan sebab ia tidak dipersalahkan oleh masyarakat serta dapat mencari solusi dengan cara menikah lagi (poligami) atau berhubungan dengan budak perempuan untuk memperoleh keturunan.

Di dalam kitab Yeremia terdapat kesan bahwa demi memenuhi keinginan memperoleh keturunan tersebut, bangsa Israel sampai melakukan hal yang mendukakan hati Allah. Nabi Yeremia memperhatikan suatu kebiasaan kafir yang umum: kaum wanita Yehuda meremas adonan, memberi korban curahan, dan membakar dupa kepada "ratu surga" untuk menjamin kesuburan (Yeremia 44:17-19; 7:18). "Ratu" yang disebut dalam ayat-ayat ini kemungkinan adalah Asytoret, dewi kesuburan. ${ }^{25} \mathrm{Hal}$ tersebut sekali lagi menunjukkan bahwa keinginan untuk memperoleh keturunan dan lepas dari masalah kemandulan begitu kuat dalam kehidupan setiap keluarga Israel.

\section{ALASAN PENTINGNYA KETURUNAN BAGI KELUARGA ISRAEL}

Pada bagian sebelumnya telah dijelaskan mengenai arti penting keturunan sebagai penjamin bagi Israel serta kemandulan sebagai keadaan yang sangat tidak diharapkan oleh setiap keluarga Israel. Pada bagian ini akan ditelusuri lebih lanjut pertanyaan mengapa hal memiliki keturunan tersebut sangat penting bagi setiap keluarga Israel.

Leo G. Perdue dalam bukunya, "Families in Ancient Israel" memperlihatkan beberapa fungsi keluarga yang meliputi fungsi ekonomi, reproduksi, pendidikan, pemeliharaan (nurture), militer dan hukum. ${ }^{26}$ Berangkat dari pengelompokkan Perdue tersebut, maka dalam tulisan ini akan dirumuskan 3 alasan utama mengenai pentingnya anak (keturunan) bagi keluarga Israel yang meliputi alasan ekonomi, keamanan dan penghormatan leluhur.

\section{Alasan Ekonomi}

Keturunan dalam keluarga Israel sangat penting dari segi ekonomi sebab adanya anak-anak dalam jumlah yang banyak (khususnya laki-laki) akan sangat membantu pekerjaan keluarga Israel sebagai bagian dari masyarakat agraris. ${ }^{27}$ Pekerjaan berat seperti berladang dan menggembalakan ternak tentu membutuhkan sumber daya manusia dalam jumlah yang besar. Hal tersebut dipertegas oleh tulisan Perdue yang menunjukkan bahwa kegiatan pertanian di Israel tidak hanya melibatkan laki-laki dewasa, tetapi juga perempuan serta anak laki-laki dan anak perempuan tertua. ${ }^{28}$ Oleh sebab itu, menurut penulis, tidak mengherankan apabila mengandung dan melahirkan anak menjadi cara paling logis yang ditempuh oleh keluarga Israel pada saat itu (untuk menyediakan tenaga kerja). Pekerjaan tersebut bisa saja dikerjakan oleh para budak, akan tetapi hal tersebut hanya berlaku bagi keluarga Israel yang memiliki banyak harta (orang kaya). Hal tersebut kembali mempertegas fakta bahwa kelahiran anak merupakan hal yang sangat diharapkan untuk menambah jumlah anggota keluarga Israel. $^{29}$ 


\section{Alasan Keamanan}

Keluarga Israel dengan anggota dalam jumlah yang besar (extended family) berfungsi sebagai pertahanan terhadap musuh yang hendak menyerang mereka. ${ }^{30}$ Perdue mengangkat kisah dalam Hakimhakim 5 yang menceritakan tentang koalisi dari suku-suku dan klan Israel untuk berperang melawan orang Kanaan (Hak. 6:33-35). ${ }^{31}$ Pada bagian sebelumnya juga telah disinggung sebuah teks yang mengatakan, "Saudara kami, moga-moga engkau menjadi beribu-ribu laksa, dan moga-moga keturunanmu menduduki kotakota musuhnya" (Kejadian 24:60). Ucapan tersebut adalah harapan dari keluarga Ribka sebelumnya ia pergi ke rumah mertuanya untuk menjadi istri Ishak. Hal itu mengindikasikan bahwa jumlah anggota yang banyak akan menyediakan jumlah tentara yang banyak pula. Jumlah tentara yang banyak tentunya akan menunjang sekaligus menjadi jaminan untuk memperoleh kemenangan atas lawan-lawan mereka. Un-tuk memperoleh angkatan perang yang banyak tentu memerlukan persiapan dan waktu yang panjang. Dalam konteks zaman itu, memiliki keturunan merupakan langkah awal untuk mencapai tujuan tersebut. Semakin banyak jumlah anggota keluarga yang dimiliki, maka semakin besar potensi bagi keluarga tersebut untuk bertahan hidup dalam konteks budaya dan masyarakat yang keras pada saat itu.

\section{Alasan Penghormatan (kepada Leluhur)}

Di dalam 2 Samuel 14:4-7 terdapat kisah menarik tentang seorang janda yang memiliki dua anak laki-laki. Kedua anak laki-laki dari janda tersebut terlibat pertengkaran yang berakhir dengan tewasnya seorang dari mereka. Anak laki-laki yang bersalah tersebut dituntut dan diancam dengan hukuman mati. Akan tetapi janda tersebut memohon di hadapan raja, "Mereka hendak memusnahkan keturunanku yang masih tersisa itu dengan tidak meninggalkan nama atau keturunan bagi suamiku di muka bumi" (2 Samuel 14:7b). ${ }^{32}$ Kisah tersebut menunjukkan bahwa seorang anak laki-laki harus tetap hidup untuk meneruskan nama orang tuanya. Akan tetapi, dari kisah tersebut juga dapat ditarik sebuah kesim- pulan bahwa meninggal tanpa seorang keturunan merupakan keadaan yang tidak diinginkan oleh setiap orangtua di Israel.

Pandangan menarik terkait dengan hal tersebut diungkapkan oleh Perdue yang mengatakan bahwa dalam pengertian figuratif, orang yang telah meninggal akan bertahan hidup (survive) melalui keberadaan keluarga (keturunan) dan pemeliharaan makam keluarga yang berada di tanah keluarga. ${ }^{33}$ Adanya keturunan akan memberikan jaminan bagi seseorang untuk meninggal dalam damai (rest in peace). Kemungkinan hal tersebut juga mendasari harapan janda dalam kisah di atas. Ia tidak ingin dirinya dan suaminya yang telah meninggal, kehilangan anak sehingga mereka mati tanpa seorang anak untuk mengurus makam mereka. Pandangan yang lebih jelas terkait dengan persoalan ini diungkapkan oleh Klaas Spronk yang memperlihatkan bahwa orang Israel di Perjanjian Lama seperti halnya masyarakat Timur Dekat Kuno - sangat mengenal dan melakukan praktik penyembahan leluhur (cult of ancestors). Spronk menunjuk kepada beberapa teks misalnya Yeremia 16:6-8 yang berisi larangan bagi orang Israel untuk pergi ke tempat yang memperingati perkabungan untuk orang mati atau atau sebagaimana yang tertuang dalam Yesaya 8:19. ${ }^{34}$

Selain itu, salah satu contoh yang (mungkin) paling terkenal adalah kisah Saul yang meminta pertolongan perempuan di En-Dor untuk memanggil arwah Samuel (1 Samuel 28). Hal tersebut mengindikasikan bahwa - meskipun praktik tersebut dilarang - namun sebagian orang Israel masih memegang pemahaman tersebut dan tradisi tersebut diturunalihkan kepada anak dan cucu mereka. Keyakinan tersebut tentunya berakar dari keyakinan bahwa orang yang sudah meninggal masih dapat berhubungan dengan orang atau keluarga yang masih hidup. Oleh karena itu, -bertolak dari pemaparan Perdue sebelumnya- dapat dipahami salah satu alasan seseorang mengharapkan keturunan adalah agar ia kelak dapat dimakamkan oleh keturunannya di tanahnya sendiri. Meninggal tanpa keturunan akan menimbulkan masalah sebab bukan hanya karena tidak ada keturunan yang akan menguburkan, tetapi juga karena tidak akan 
ada yang merawat makam mereka termasuk (mungkin) memberikan mereka makanan/ persembahan. Praktik penghormatan leluhur ini juga didukung oleh penemuan arkeologi di kota kuno Qatna pada tahun 2002 berupa piring-piring dan tulang binatang yang diyakini sebagai persembahan bagi orang yang telah meninggal. ${ }^{35}$

\section{SUMBANGSIH PEMAHAMAN ALKITABIAH TENTANG KETURUNAN DAN KEMANDULAN BAGI KEHIDUPAN UMAT MASA KINI}

Setelah mengetahui arti penting keturunan dan persoalan kemandulan dalam Alkitab, bagian ini akan memperlihatkan sumbangsih pemahaman alkitabiah bagi kehidupan keluarga kristen yang hidup pada masa kini. Sebelumnya, perlu diingat kembali bahwa Alkitab, khususnya Perjanjian Lama bukanlah buku teks yang memberikan rumusan yang jelas dan sistematis terhadap topik tertentu. Demikian halnya dengan konsep keluarga yang ideal. Alkitab hanya memberikan narasi mengenai kehidupan keluarga-keluarga tertentu pada masa itu. Meskipun demikian, bukan berarti bahwa kita tidak dapat menarik pelajaran mengenai kehidupan keluarga pada zaman tersebut dan melihat kontribusinya bagi kehidupan umat masa kini.

Ketiadaan anak dalam keluarga seringkali dianggap oleh sebagian orang sebagai hal yang kurang wajar bahkan seringkali menjadi bahan pembicaraan (entah secara sengaja atau tidak). Justru di sini gereja memiliki peran besar untuk meluruskan pemahaman yang keliru tentang keturunan dan kemandulan. Gereja perlu memberikan pemahaman yang benar sehingga pasangan yang belum memilki anak tidak perlu merasa malu di dalam komunitasnya sendiri dan memikirkan solusi instan seperti bercerai atau menikah lagi. Dengan memberikan pemahaman yang tepat, maka jemaat, khususnya pasangan suami-istri yang belum memiliki anak tidak perlu merasa malu, apalagi berpikir bahwa kemandulan adalah hukuman dari Tuhan.

Perjanjian Lama memang memperlihatkan bahwa sistem atau kondisi masyarakat pada zaman itu memandang bahwa tujuan utama dari perkawinan adalah untuk membangkitkan keturunan. Hal tersebut terlihat dari dua bentuk perkawinan yang ada, poligami dan levirat. Terhadap bentuk perkawinan tersebut, di satu sisi, pembaca masa kini sebaiknya tidak buru-buru menjatuhkan tuduhan bahwa hal tersebut adalah tindakan sewenang-wenang dari pihak laki-laki (suami) kepada pihak perempuan (istri). Kemungkinan, untuk konteks zaman itu, hal tersebut adalah lumrah sekaligus tuntutan pada zaman itu (misalnya untuk menyediakan angkatan perang dalam jumlah yang besar agar dapat bertahan hidup). Akan tetapi, di sisi lain, bentuk perkawinan yang tercatat dalam Alkitab tersebut juga tidak dapat dijadikan sebagai dasar pembenaran bagi perkawinan di masa kini. Oleh sebab itu, perceraian dan poligami sebagai alasan untuk memperoleh keturunan tidak dapat dibenarkan karena tidak sesuai dengan konteks zaman yang telah berubah. Ketika konteks berubah, seharusnya tuntutan dan paradigma berpikir masyarakat juga ikut berubah. Perlu diingat kembali bahwa bentuk perkawinan yang umum pada zaman Alkitab adalah monogami. Prinsip tersebut juga tertuang dalam Kejadian 1 dan 2. ${ }^{36}$ Perkawinan pada masa kini seharusnya tidak didasari dengan tujuan untuk mendapatkan anak. Keinginan tersebut memang tidak keliru dan berdosa, tetapi seharusnya tidak menjadi tujuan utama. Menurut Albertus Purnomo, tujuan pernikahan harus dipahami dalam kedewasan iman bahwa setiap suami-istri dipanggil untuk menikmati kebersamaan secara eksklusif dalam rangka perjanjian -dengan Allah sebagai inisiatornya- melalui cinta di antara pasangan suami-istri tersebut. ${ }^{37}$

Sementara itu, berhadapan dengan persoalan kemandulan yang dianggap sebagai hukuman dari Tuhan, Phyllis Trible dalam bukunya yang berjudul God and the Rhetoric of Sexuality memberikan pemaparan yang menarik. Trible mengangkat tiga kisah yaitu Sara di istana Abimelekh, Lea dan Rahel, serta Hana untuk memperlihatkan bahwa di Perjanjian Lama, Allah digambarkan sebagai sang empunya rahim (kandungan). ${ }^{38}$ Allah melindungi Sara dengan cara menutup kandungan setiap perempuan dalam istana Abimelekh sebagai bentuk hukuman karena 
ia mengambil istri Abraham - walaupun atas persetujuan Abraham sendiri - (Kej. 20:118). Dalam kisah lain diceritakan bahwa Allah sendirilah yang membuka kandungan Lea sebagai bentuk berkatnya bagi Lea. Selain itu, Allah juga yang mengingat dan membuka kandungan Rahel serta Hana setelah sebelumnya menutup kandungan tersebut. Apabila dalam kisah Sara dan Abimelekh, Allah menutup kandungan sebagai bentuk hukuman, maka tidak ada penjelasan mengapa dalam kisah Rahel dan Hana, Allah menutup kandungan mereka sebelumnya, akan tetapi setelah itu, Ia mengingat dan membuka kandungan mereka. Tidak disebutkan pula bahwa tindakan tersebut adalah hukuman atas dosa perempuan-perempuan tersebut di masa lalu. Hal itu menjadi kedaulatan dan misteri Allah. ${ }^{39}$ Kisah tersebut memperlihatkan bahwa kontrol atas rahim perempuan bukan berada pada perempuan atau sang suami, tetapi hanya Allah yang berkuasa membuka dan menutup kandungan dalam penghukuman, berkat dan misteri. ${ }^{40}$ Dengan demikian, kecuali kisah Abraham dan Sara di istana Abimelekh, dapat disimpulkan bahwa kemandulan tidak identik dengan hukuman Allah. Penulis menarik kesimpulan bahwa isah-kisah tentang perempuan mandul dalam Alkitab diangkat untuk menekankan bahwa Allah sendiri yang berkuasa mengatur siapa yang dapat mengandung, kapan dan bagaimana mereka dapat mengandung. Jadi tidak terkait dengan hukuman Allah atas pasangan suami-istri tersebut.

Setelah memiliki pemahaman yang tepat mengenai kemandulan, jemaat juga perlu memahami ulang hal memiliki anak/keturunan. Pada bagian sebelumnya telah disinggung bahwa anak adalah milik pusaka Tuhan, demikian dikatakan dalam Mazmur 127:3. Anak adalah milik Tuhan! Melalui prinsip alkitabiah ini, keluarga-keluarga Kristen disadarkan bahwa anak bukanlah milik keluarga secara eksklusif. Kehadiran anak dalam sebuah keluarga semata-mata adalah pemberian atau anugerah Tuhan. Menurut penulis, apabila orang Kristen sungguh-sungguh menyadari anak sebagai pemberian yang hanya diperoleh karena kemurahan Tuhan, maka belum atau tidak adanya anak dalam sebuah keluarga seha- rusnya tidak dipandang sebagai persoalan yang sangat besar. Ketika anak-anak belum hadir dalam sebuah keluarga, hal tersebut kemungkinan karena Tuhan belum berkenan memberikan anugerah-Nya berupa keturunan sehingga manusia hanya dapat berusaha, namun tidak perlu sampai memaksakannya. ${ }^{41}$

Bagi mereka yang pada akhirnya tidak dikaruniai anak, mungkin Allah memiliki maksud agar mereka (pasangan suamiisteri) dapat menggunakan waktu dan kebebasannya untuk melayani dan bekerja secara maksimal - sesuatu yang mungkin tidak sepenuhnya dapat dikerjakan oleh mereka yang mempunyai anak. ${ }^{42}$ Selain itu, kemandulan juga dapat digunakan sebagai sebuah kesempatan untuk mengadopsi, sebuah anugerah baik bagi anak yang akan diadopsi maupun bagi orang tua yang mau mengadopsi. ${ }^{43}$ Akan tetapi adopsi seharusnya tidak dimaknai hanya sekadar solusi bagi yang tidak memiliki anak, sebab jika demikian, akan timbul degradasi nilai dari adopsi: adopsi merupakan sebuah pelarian. Adopsi harus dimaknai pula sebagai komitmen pasangan suami-istri di hadapan Allah untuk menjadi orang tua. Setiap keluarga dapat diajak untuk memperhatikan kehidupan orang lain dengan cara mengangkat anak, sebab ada banyak anak di dunia ini yang tidak memiliki orangtua. Langkah alternatif ini perlu diperkenalkan sebab entah disadari atau tidak, keinginan memperoleh anak seringkali dipaksakan untuk memenuhi ego, melayani kepentingan diri sendiri. Tidak heran jika anak seringkali dianggap sebagai aset (bukan sebagai pribadi) untuk kehidupan di masa mendatang.

Menurut penulis, tindakan mengangkat anak bukanlah sebagai pancingan untuk memperoleh keturunan - sebagaimana yang dipahami dan dipercaya oleh sebagian orang saat ini - melainkan sebagai salah satu wujud dari penghargaan dan ungkapan syukur terhadap kehidupan yang diberikan Tuhan. Dengan mengangkat anak, maka pasangan suami-istri tersebut secara sadar mengambil sebuah tanggung jawab sebagai orangtua, (meskipun anak tersebut adalah anak angkat) sekaligus menjalankan mandat dari Tuhan. 
Hal yang sama juga berlaku bagi keluarga yang telah diberikan anugerah berupa keturunan. Ketika keluarga tersebut memiliki anak, hendaknya mereka tidak menganggapnya sebagai hal yang lumrah dan wajar (taken for granted) atau sebaliknya, merasa bangga karena memiliki keturunan. Keluarga tersebut perlu mengingat kembali bahwa anak-anak tersebut hadir dalam keluarga mereka karena Tuhan mau, berkenan, dan berkehendak atas hal tersebut. Tuhan memberikan anugerah-Nya berupa keturunan. Itu sebabnya keluarga yang memiliki anak juga tidak dapat berlaku sewenang-wenang, apalagi sampai menelantarkan anak mereka. Sebab anak-anak tersebut bukanlah milik mereka sendiri, anak-anak tersebut adalah milik Tuhan, milik pusaka Tuhan.

\section{PENUTUP}

Harapan untuk memiliki keturunan masih dianggap sebagai hal yang sangat penting bagi masyarakat masa kini. Itu sebabnya ketidakhadiran seorang anak akan menjadi persoalan, khususnya bagi pasangan suami-istri yang telah lama menikah. Dengan demikian, kemandulan menjadi kabar buruk yang tidak diharapkan dan tidak ingin didengar oleh setiap pasangan suamiistri. Berhadapan dengan persoalan tersebut, jemaat perlu diajak untuk membingkai ulang (reframing) pemahaman yang selama

\section{CATATAN AKHIR}

${ }^{1}$ Badan Pusat Statistik, "Penduduk Indonesia Menurut Provinsi 1971, 1980, 1990, 1995, 2000 dan 2010.

http://www.bps.go.id/tab_sub/view.php?tabel=1\&id_ subyek=12 (diakses 26 Februari 2017).

2 Departemen Kesehatan Republik Indonesia, "Situasi dan Analisis Keluarga Berencana." http://www.depkes.go.id/resources/download/pusdat in/infodatin/infodatin-harganas.pdf (diakses 12 Maret 2017).

3 Tjok Istri Putra Astiti, "Nilai Anak dalam Kehidupan Keluarga Orang Bali," dalam Bunga Rampai Sosiologi Keluarga, peny. T. O. Ihromi (Jakarta: Yayasan Obor Indonesia, 1999), 226.

${ }^{4}$ Harahap dan Siahaan mengatakan: "Hagabeon sama artinya dengan "bahagia dan sejahtera." Kebahagiaan yang dimaksudkan di sini adalah kebahagiaan dalam hal memiliki keturunan. Keturunan dipandang sebagai pemberi harapan hidup karena keturunan adalah kebahagiaan yang tidak ternilai bagi orangtua, keluarga, dan kerabat. ini mereka pegang. Memiliki anak bukanlah tujuan utama dalam perkawinan. Perkawinan adalah wadah yang disediakan oleh Allah bagi laki-laki dan perempuan untuk menikmati kebersamaan secara eksklusif. Kehadiran anak hanyalah salah satu dari aspek perkawinan tersebut dan kehadirannya merupakan anugerah dari Allah sendiri. Keluarga yang diberikan anugerah tersebut sudah sepatutnya mengucap syukur dan memandangnya sebagai tanggung jawab yang harus dilaksanakan dengan penuh perhatian. Sebaliknya, keluarga yang belum memiliki anak diajak untuk bersabar dan menerima keadaan yang ada. Usaha dari pasangan dapat tetap dilakukan tetapi tidak dengan menghalalkan segala macam cara, sebab mungkin Allah di dalam kedaulatanNya memang belum berkenan memberikan anugerah-Nya. Mungkin Allah memiliki rencana lain dalam kehidupan pasangan suami isteri tersebut. Rencana Allah tersebut mungkin tak terselami pikiran manusia, namun rancangan Allah tersebut dapat dirasakan melalui perjalanan iman pasangan suami isteri tersebut.

\section{Yohanes K. Susanta.}

Alumuni MTh dari STT Jakarta dalam bidang Perjanjian Lama. Menjadi staff pengajar di Sekolah Tinggi Agama Kristen Negeri (STAKN) Toraja.

Hamoraon (kekayaan) adalah segala sesuatu yang dimiliki oleh seseorang di mana kekayaan ini diidentikkan dengan harta kekayaan dan anak. Hasangapon (kemuliaan dan kehormatan) merupakan kedudukan seseorang dalam lingkungan masyarakat. Untuk mencapai hasangapon seseorang harus terlebih dahulu berketurunan (gabe) dan memiliki kekayaan (mora)" Basyral Hamidy Harahap dan Hotman Siahaan, Orientasi Nilai-nilai Budaya Batak Toba: Suatu Pendekatan Terhadap Perilaku Batak Toba dan Angkola-Mandailing (Jakarta: Sanggar Willem Iskandar, 1987), 85.

${ }^{5}$ Basyral Hamidy Harahap dan Hotman Siahaan, Orientasi Nilai-nilai Budaya Batak Toba: 136.

${ }^{6}$ Astiti, "Nilai Anak dalam Kehidupan Keluarga Orang Bali," 227.

7 Astiti, "Nilai Anak...", 228.

8 Astiti, "Nilai Anak...", 228-229.

9 T. O. Ihromi, Adat Perkawinan Toraja Sa'dan dan Tempatnya dalam Hukum Positif. Jakarta: Gadjah Mada University Press dan Yayasan Obor Indonesia, 1981), 111-116 
10 Roland de Vaux, Ancient Israel Volume 1: Social Institutions (New York: McGraw-Hill Book Company, 1965), 25.

11 Daniel I. Block, "Marriage and Family in Ancient Israel," dalam Marriage and Family in the Biblical World, peny. Ken M. Campbell (Louisville: InterVarsity Press, 2003), 44.

12 de Vaux, Ancient Israel Volume 1: Social Institutions, 25.

13 de Vaux, Ancient, 25.

14 Hal tersebut tidak mengherankan sebab gagasan atau gambaran tentang perkawinan monogami tercermin di dalam kitab Kejadian melibatkan dua pribadi (seringkali dipahami sebagai dasar dari perkawinan monogami). Hal tersebut juga didukung oleh tulisan de Vaux sebelumnya yang mengatakan bahwa perkawinan monogami adalah bentuk umum yang berlaku di Israel.

15 de Vaux, Ancient, 37.

16 Kisah Rut dan Boas adalah salah satu contoh perkawinan levirat yang unik. Kerabat yang terdekat tidak bersedia menikahi Rut. Oleh karena itu Boas, sebagai kerabat terdekat berikutnya, bertindak sebagai kerabat penebus. Setelah membayar utang atas tanah pusaka Elimelekh, Boas mengambil Rut menjadi istrinya "untuk menegakkan nama orang yang telah mati itu di atas milik pusakanya. Demikianlah nama orang itu tidak akan lenyap dari antara saudara-saudaranya dan dari antara warga kota" (ut 4:10). Lih. Ensiklopedi Fakta Alkitab, s.v. "Pernikahan dan Perceraian" (Malang: Gandum Mas, 2001), 787.

17 Ensiklopedi Fakta Alkitab, 787.

18 Ensiklopedi Fakta Alkitab, s.v. "Kelahiran dan Masa Bayi" (Malang: Gandum Mas, 2001), 782.

19 Y. M. Seto Marsunu, "Pendidikan Iman Anak dalam Perjanjian Lama dan Tradisi Yahudi," Wacana Biblika Vol. 13 No. 4 (Oktober-Desember 2013): 148.

20 Marsunu, "Pendidikan Iman Anak dalam Perjanjian Lama dan Tradisi Yahudi," 148-149.

21 Leo G. Perdue, "The Israelite and Early Jewish Family: Summary and Conclusions," dalam Families in Ancient Israel, peny. Don S. Browning dan Ian S. Evison (Louisville: Westminster John Knox Press, 1997), 170.

22 Dictionary of Biblical Imagery, s.v. "Barrenness" (Downers Grove: Intervarsity Press, 2000), 1032.

23 Maura A. Ryan, Ethics and Economics of Assisted Reproduction (Washington: Georgetown University Press, 2003), 52.

24 Ketika Rahel yang putus asa karena belum memiliki anak mengatakan, "Berikanlah kepadaku anak; kalau tidak, aku akan mati” (Kej. 30:1). Yakub memberikan jawaban yang tidak kalah sengit, "Akukah pengganti Allah, yang telah menghalangi engkau mengandung?" (Kej. 30:2).

25 Ensiklopedi Fakta Alkitab, s.v. "Kelahiran dan Masa Bayi” (Malang: Gandum Mas, 2001), 783.

26 Perdue, "The Israelite and Early Jewish Family: Summary and Conclusions," 168-174.

27 Perdue, "The Israelite...", 168.

28 Perdue, "The Israelite...", 169.

29 Hal tersebut (alasan ekonomi) - dari sudut pandang logika - sebenarnya mengandung risiko dan agak aneh. Kenyataannya, semakin banyak anak, maka semakin besar biaya yang diperlukan. Akan tetapi risiko tersebut tampaknya terpaksa diambil oleh keluarga Israel sebagai langkah antisipasi dan persiapan untuk mengerjakan setiap pekerjaan berat dalam keluarga tersebut.

30 Perdue, "The Israelite ...," 171.

31 Perdue, "The Israelite ...," 171

32 Ensiklopedi Fakta Alkitab, s.v. "Kelahiran dan Masa Bayi” (Malang: Gandum Mas, 2001), 785.

33 Perdue, "The Israelite and Early Jewish Family: Summary and Conclusions," 170.

34 Klaas Spronk, "The Ancestors in the Religion of Ancient Israel and in Christian Theology: A Contribution to the Intercultural Reading of the Bible," Gema Teologi Vol. 34 No. 1 (April 2010): 29.

35 Spronk, "The Ancestors in the Religion of Ancient Israel and in Christian Theology,": 28-29.

36 Kejadian 1 dan 2 tentu tidak dapat dipahami sebagai perkawinan dalam pengertian modern, tetapi secara tradisional diterima bahwa gagasan mengenai perkawinan monogami tercermin di dalam kitab tersebut. Laki-laki dan perempuan dipersatukan oleh Allah menjadi satu daging dan perceraian tidak dibenarkan oleh Allah.

37 Meskipun dalam Perjanjian Lama, unsur cinta seringkali dianggap bukan faktor utama bagi pasangan yang akan menikah (sebab pasangan tersebut biasanya dijodohkan). Akan tetapi beberapa bagian Alkitab seperti kitab Kidung Agung memberikan sudut pandang lain tentang ungkapan cinta sebagai fondasi yang memperkuat ikatan pernikahan seseorang, bukan semata-mata untuk memperoleh keturunan. Lih. Albertus Purnomo, "Antara Kontrak dan Cinta: Perkawinan dalam Perjanjian Lama," Wacana Biblika Vol. 13 No. 1 (Januari-Maret 2013): 10.

38 Phyllis Trible, God and the Rhetoric of Sexuality, edisi ketiga (Philadelphia: Fortress Press, 1983), 34.

39 Phyllis Trible, God and the Rhetoric, 35.

40 Phyllis Trible, God and the Rhetoric, 35.

41 Pandangan ini tidak bermaksud untuk menyederhanakan masalah kemandulan sebab hal tersebut merupakan persoalan yang tidak begitu populer namun sangat sensitif. Oleh sebab itu perlu diberikan pemahaman teologis untuk menerima kehendak Allah tersebut secara bertahap dan hatihati.

42 Ashmon Scott and Robert W. Weise, "Give Me Children, or I Will Die: Procreation Is God's Work," Concordia Journal (Oktober 1998): 344-345.

43 Ashmon Scott. "Give Me Children, ...", 347.

\section{DAFTAR RUJUKAN}

\section{Buku}

Astiti, Tjok Istri Putra "Nilai Anak dalam Kehidupan Keluarga Orang Bali," dalam Bunga Rampai Sosiologi Keluarga, peny. T. O. Ihromi. 226238. Jakarta: Yayasan Obor Indonesia, 1999. 
Block, Daniel I. "Marriage and Family in Ancient Israel,"dalam Marriage and Family in the Biblical World. Peny. Ken M. Campbell. 33-102. Louisville: InterVarsity Press, 2003.

de Vaux, Roland. Ancient Israel Volume 1: Social Institutions. New York: McGraw-Hill Book Company, 1965.

Harahap, Basyral Hamidy dan Hotman Siahaan. Orientasi Nilai-nilai Budaya Batak Toba: Suatu Pendekatan Terhadap Perilaku Batak Toba dan Angkola-Mandailing. Jakarta: Sanggar Willem Iskandar, 1987.

Ihromi, T. O. Adat Perkawinan Toraja Sa'dan dan Tempatnya dalam Hukum Positif. Yogyakarta dan Jakarta: Gadjah Mada University Press dan Yayasan Obor Indonesia, 1981.

Perdue,Leo G. "The Israelite and Early Jewish Family: Summary and Conclusions," dalam Families in Ancient Israel. Peny. Don S. Browning dan Ian S. Evison. 163-222. Louisville: Westminster John Knox Press, 1997.

Ryan, Maura A. Ethics and Economics of Assisted Reproduction. Washington: Georgetown University Press, 2003.

Tinambunan, Djapiter dan Rayendra L. Toruan. Orang Batak Kasar? Membangun Citra dan Karakter. Jakarta: Elex Media Komputindo, 2010.

Trible, Phyllis. God and the Rhetoric of Sexuality, edisi ketiga. Philadelphia: Fortress Press, 1983.

Vergouwen, Jacob Cornelis. Masyarakat dan Hukum Adat Batak Toba. Yogyakarta: LkiS, 2004.

\section{Jurnal dan Majalah}

Ashmon Scott and Robert W. Weise. "Give Me Children, or I Will Die: Procreation Is God's Work." Concordia Journal (Oktober 1998): 337-345.
Marsunu, Y. M. Seto. "Pendidikan Iman Anak dalam Perjanjian Lama dan Tradisi Yahudi." Wacana Biblika, Vol. 13 No. 4 (Oktober-Desember 2013): 147-158.

Purnomo, Albertus. "Antara Kontrak dan Cinta: Perkawinan dalam Perjanjian Lama," Wacana Biblika Vol. 13 No. 1 (Januari-Maret 2013): 3-10.

Spronk, Klaas. "The Ancestors in the Religion of Ancient Israel and in Christian Theology: A Contribution to the Intercultural Reading of the Bible." Gema Teologi, Vol 34 No. 1 (April 2010): 24-34.

\section{Kamus dan Ensiklopedi}

Packer, J. I., Merrill C. Tenney, William White Jr, peny. Ensiklopedi Fakta Alkitab 2. Terj. Johan C. Pandelaki dan Sutrisno. Malang: Gandum Mas, 2001. S.v. Kelahiran dan Masa Bayi.

. Ensiklopedi Fakta Alkitab 2. Terj. Johan C. Pandelaki dan Sutrisno. Malang: Gandum Mas, 2001. S.v. Pernikahan dan Perceraian.

Ryken, Leland, Jim Wilhoit, dan Tremper Longman III, peny. Dictionary of Biblical Imagery. Downers Grove: InterVarsity Press, 2000. S.v. Barrenness.

\section{Internet}

Badan Pusat Statistik. "Penduduk Indonesia Menurut Provinsi 1971, 1980, 1990, 1995, 2000 dan 2010. “ http://www.bps.go.id/tab_sub/view.php?t abel=1\&id_subyek=12 (diakses 26 Februari 2017).

Departemen Kesehatan Republik Indonesia. "Situasi dan Analisis Keluarga Berencana." http://www.depkes.go.id/resources/do wnload/pusdatin/infodatin/infodatinharganas.pdf (diakses 12 Maret 2017). 
